\title{
The Kap København Formation, a late Cainozoic sedimentary sequence in North Greenland
}

\author{
Svend Funder, Ole Bennike, Gert Steen Mogensen, Bodil Noe-Nygaard, \\ Stig A. Schack Pedersen and Kaj Strand Petersen
}

The Kap København sequence is a $c .300 \mathrm{~km}^{2}$ deposit of unconsolidated sand, silt and clay, more than $100 \mathrm{~m}$ thick, on the shores of Independence Fjord, lat. 82 $30^{\prime} \mathrm{N}$, in eastern Peary Land (fig. 3). The sediments contain abundant well preserved plant and animal remains, probably Pliocene or Pleistocene.

The occurrence was first discovered in 1979 by Funder \& Hjort (1980). Later, analyses of organic remains gave interesting results (Fredskild \& Røen, 1982; Mogensen, in press), and in 1983 the sediments were the object of a detailed study during a combined geological and biological expedition to the area. This report presents the first results from this expedition, and formally names the sediments the Kap København Formation.

The sediments of the Kap København Formation form a characteristic landscape of elongated hills with altitudes up to $230 \mathrm{~m}$ above sea level. The hills are the eroded remnants of a once continuous deposit that extended from Vitskøl Elv in the west and beyond Mudderbugt in the east, where it disappears below younger glacial deposits. To the north the sediments terminate abruptly on the south bank of Ladegårdsåen, while in the south they are eroded and disappear under glacial and Holocene marine sediments along the coast (fig. 4).

\section{Lithology}

The lithology and sedimentary structures of the Kap København Formation are illustrated by two generalised sections (fig. 5). Section 1, the type locality for the formation, is $4 \mathrm{~km}$ south-west of Kap København. It is the locality shown by Funder \& Hjort (1980, fig. 44).

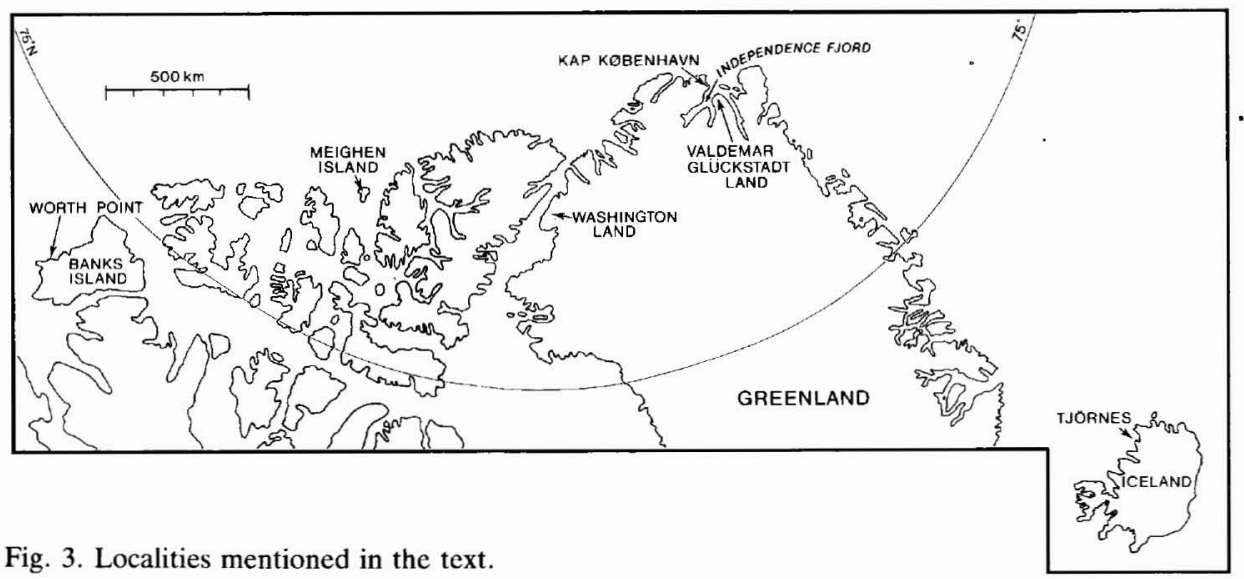

Fig. 3. Localities mentioned in the text. 


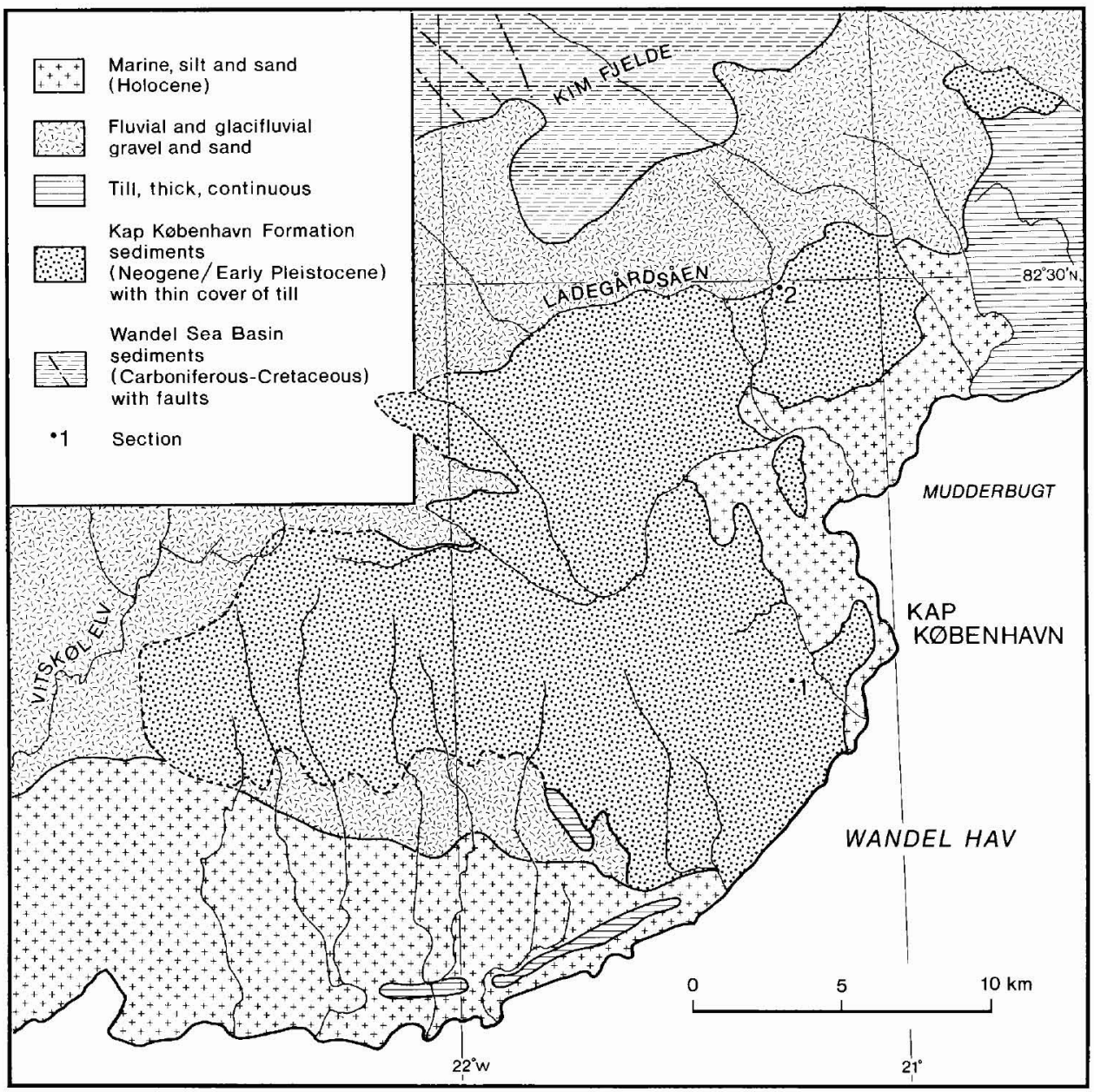

Fig. 4. Geology of the Kap København area. Distribution of Wandel Sea Basin sediments from Håkansson, 1979.

Section 2 which has a slightly different sedimentary facies is near Ladegårdsåen $15 \mathrm{~km}$ to the north.

The base of the formation is nowhere exposed, while its top is eroded and unconformably overlain by till. The total thickness of the formation is unknown, but it is at least $100 \mathrm{~m}$.

In all parts of the area two distinct sedimentary units can be differentiated. The lowermost, member A, is composed of finely laminated, red or grey clay and silt. The thickness of this member is more than $50 \mathrm{~m}$, but its base is not exposed in the area.

The contact between member $A$ and the overlying member B is frequently marked by an erosional disconformity and a hiatus. However, in section 1 the transition between the two members is gradual. The fine-grained sediments of member $\mathrm{A}$ are resistant to erosion and 


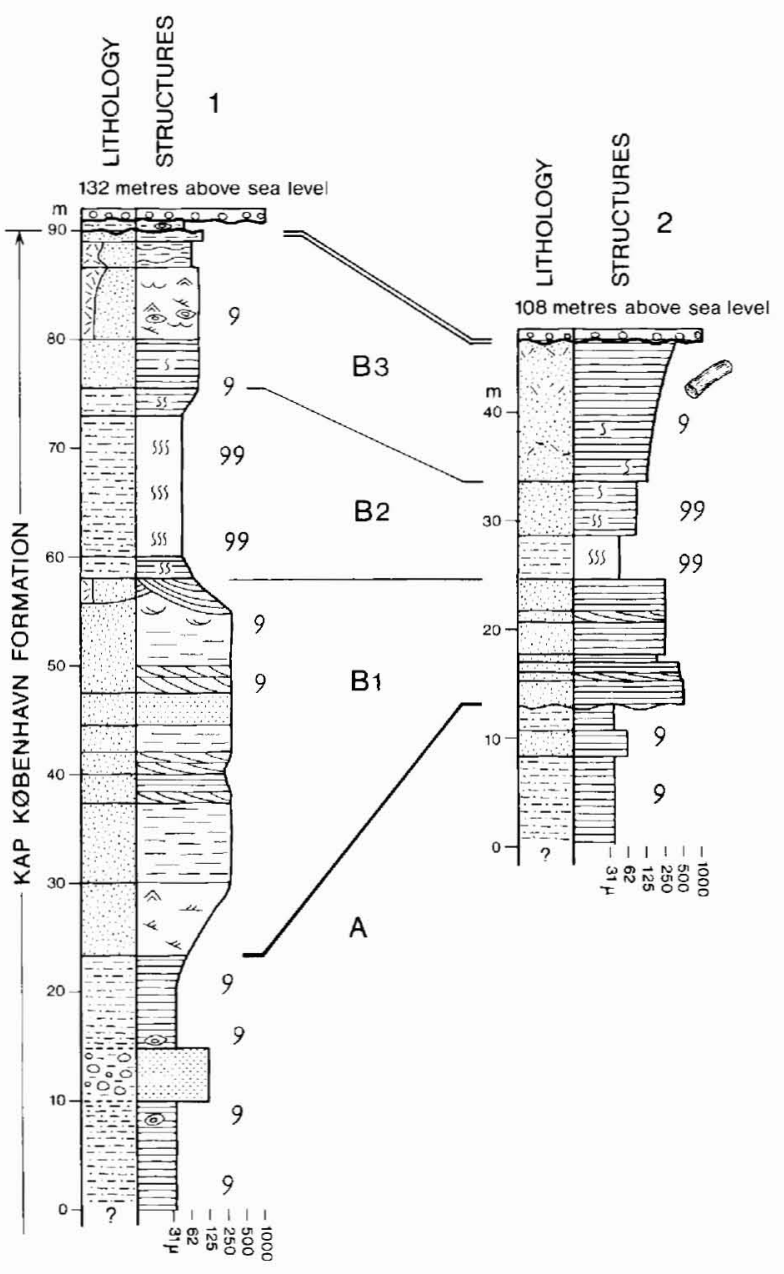

Fig. 5. Lithology and sedimentary structures of the Kap København Formation. Location of sections appears in fig. 4 .

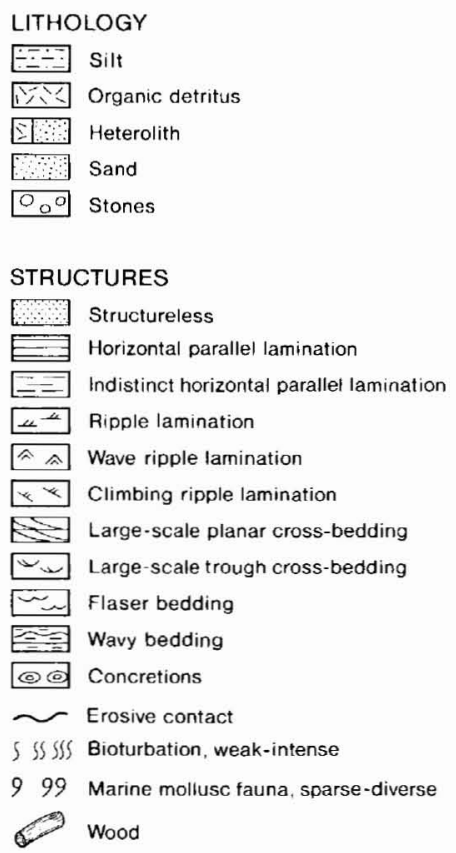

form the terrain surface in areas where the overlying member B has been removed by later erosion.

Member B, although composed mainly of sand, shows a variety of lithologies and sedimentary structures; it also shows facies variation within the area, and the correlation of its units shown in fig. 5 is tentative.

In areas around Mudderbugt member B is distinctly tripartite with a $10-15 \mathrm{~m}$ thick bed of fine-grained sediments (unit B2) overlying and overlain by the coarser units B1 and B3. The facies represented by unit $\mathbf{B} 2$ is absent from the western part of the area, and the unit is thinner in the north than in the south.

Sediments coarser than sand are rarely met with in the Kap København Formation. Matrix supported diamicton with stones and boulders of up to $0.5 \mathrm{~m}$ diameter have been observed at a few localities. The diamicton was interpreted earlier as a basal till deposit 
(Funder \& Hjort, 1980). However, recent observations show that the diamicton is incorporated in the sediments of member $\mathrm{A}$, and its very restricted occurrence indicates that it represents isolated pockets of ice-rafted detritus.

Horizontally bedded gravel has been observed in the upper part of unit B3 at one locality. The clasts are mainly rock types found in the neighbouring Kim Fjelde to the north, but, as in the diamicton mentioned above, there is a small component of quartzite and crystalline rocks which occur only to the south of Independence Fjord, and must have been transported by floating ice or glaciers.

Based on its lithology, sedimentary structures and organic remains (see below), the Kap København Formation is interpreted as a marine deposit, with a transition from deeper water in member A to shallower water in member B. Unit B2 reflects a recurrence of somewhat deeper water. In some areas beach facies are present in member B, while fluvial and lacustrine sediments may possibly occur also.

\section{Organic remains}

The Kap København Formation is characterised by its abundant organic remains comprising in situ marine mollusc shells and allochthonous remnants of limnic and terrestrial flora and fauna, occurring in 5-20 cm thick beds, or finely disintegrated in flasers and wavy bedding in units $\mathrm{B} 1$ and $\mathrm{B} 3$.

Identifications of plant, insect and moss remains from samples collected in 1979 have been published by Funder \& Hjort (1980), Fredskild \& Røen (1982), and Mogensen (in press). The large sample of material brought home in 1983 is currently being studied, and some interesting results have appeared.

Several distinct mollusc faunas have been recognised within the Formation. The laminated sediments of member A contain a sparse fauna characterised by the bivalve genera Portlandia and Musculus, while unit B2 has a more diverse type of fauna, dominated by the bivalve genera Cyrtodaria, Macoma and Astarte, as well as by small epifaunal gastropods. The intense bioturbation of this unit is probably caused by polychaetes.

Shell fragments from the robust species Mya truncata, Hiatella arctica and Astarte sp. occur frequently on the terrain surface, associated with a thin cover of glacial erratics. Preliminary results from amino acid analysis of the mollusc shells indicate that they are of the same age as the faunas mentioned above, where Mya is absent and Hiatella rare. Hence, the source of these fragments has not yet been established, although some observations indicate that they could be derived from the upper part of member $\mathrm{A}$, which has often been removed by later erosion.

The organic detritus in units B1 and B3 is dominated by moss remains and twigs, probably deposited in a near-shore environment.

The moss flora is the richest which has been recorded from any Neogene - early Pleistocene sample in the North American Continent. More than 50 species have so far been determined, including five taxa reported by Mogensen (in press). The bryophyte flora suggests the presence of a northern boreal-arctic tundra with diverse habitats: open forest, complex mire systems, ponds, streams, snowbeds, moist heath, and sea-shore. The species found most often are Scorpidium scorpioides and Calliergon sarmentosum, both very rare in North Greenland to-day. All the species which have been identified occur in Greenland at 
present, but some, e.g. Schistidium maritimum and Dicranum undulatum, have very restricted distributions in oceanic South Greenland.

The vascular flora is represented by seeds, leaves, twigs, and pollen. Pieces of word also occur abundantly in some areas associated with unit B3. The wood was earlier thought to be driftwood of Siberian origin (Funder \& Hjort, 1980), however the finding in 1983 of cones, needles and twigs, as well as stunted stems with their branches still attached and roots with tiny rootlets, show that trees grew in Peary Land at the time when the sediments accumulated.

The forest was of open northern boreal coniferous type, dominated by Picea and Larix, but containing also Taxus, Thuja, tree-Betula, Salix, and Cornus bushes. However, the vegetation was dominated by arctic dwarf shrubs: dwarf-Betula, Dryas, Vaccinium cf. uliginosum, Empetrum, Ledum, and Cassiope cf. tetragona.

Insect remains in the moss layers show the presence of several species of Coleoptera (beetles), although no living Coleoptera could be found in the area. Four species of Coleoptera of southern provenance were identified in beds of the Kap København Formation by Fredskild \& Røen (1982). Traces of insect attack can be seen in some pieces of wood and fly holes very similar to those produced today by Urocerus gigas, a species of palaearctic distribution, have been identified (B. Bejer-Petersen, personal communication, 1983). Recent collections of wood also show traces of attack from cerambycidae (longicorn beetle).

The evidence from plant and insect remains reflects an environment of open boreal forest and low arctic tundra. Summer temperatures were at least $10^{\circ} \mathrm{C}$, compared with the present $4^{\circ}$ and winters were mild, probably snowy. The ecosystems were broadly similar to present ones, and no extinct species have yet been identified.

\section{Structural geology}

The sediments of the Kap København Formation show deformation structures which can be ascribed to both syn- and post-depositional disturbances.

The earliest deformation event was synsedimentary slump-folding and meso- and macroscale slump-sliding of sediment sheets. These structures characteristically developed in the upper organic-rich units (fig. 6). The slump folds occur on a scale from a few centimetres to folds with an amplitude of $0.5 \mathrm{~m}$. Slump-folded beds may develop into allochthonous sedimentary sheets. The sheets are typically 0.5 to $1 \mathrm{~m}$ thick, $10-20 \mathrm{~m}$ in lateral extension, and have frontal noses preserved in the distal part of the systems. The peculiar and widespread slumping is most likely the result of compaction of water-saturated organic-rich sediments during rapid sedimentation on a slightly tilted substrate.

Post-depositional disturbance can be ascribed to pressure from an overriding glacier, producing 10-100 $\mathrm{m}$ thick thrust sheets, displaced in a northwards direction. The highest topographical altitudes, 200-250 m above sea level, are attained where several thrust sheets have been piled on top of one another. Mesoscopic and macroscopic tight overturned folds occur commonly in the interface between the laminated fine-grained sediments of member A and the sandy member B (fig. 7). In the organic-rich sand of unit B3 irregular folds, associated with water-escape structures and reverse faults are abundant. The décollement surface is situated in member $A$, and in the northern part of the area only thin slices of member A are present as a highly sheared sole of the thrust sheets which are steeply 


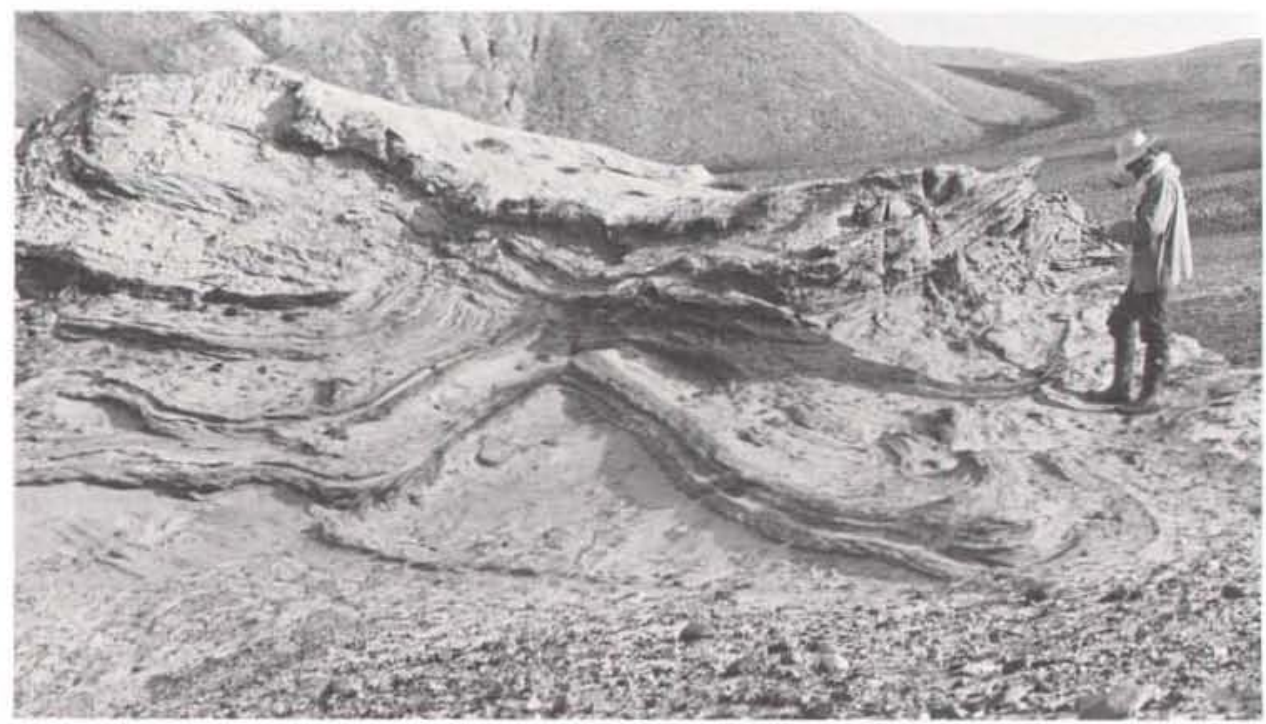

Fig. 6. Large scale slump-fold structure in sand with layers of organic detritus, member B in the Kap Kobenhavn Formation.

imbricated, probably owing to pressure against the topographic barrier at Kim Fjelde in the north.

In some areas east-west elongated hills represent the eroded remnants of dislocated thrust sheets. These escarpments have earlier, erroneously, been interpreted as terminal moraines (Koch, 1923; Davies, 1963).

Applying Kern PG2 computer-assisted photogrammetry of 1:150000 air photos, a lineament analysis of the region has been made. The analysis shows a pronounced NW-SE trending ridge and valley system, parallelling the main fault directions in the mountains of Kim Fjelde and the Trolle Land Fault Zone (Hẩkansson \& Pedersen, 1982). Owing to the lack of exposures in the sandy valley sides no field data on these lineaments are available. However, the distribution of the Kap København Formation sediments affords some speculation on their origin.

The abrupt termination of the sedimentary sequence at the major valleys of Vitskøl Elv and Ladegårdsåen cannot be explained in terms of the present topography by later erosion. It may be speculated, however, that the formation of the thick pile of sediments at Kap København was caused by uplift in Kim Fjelde, immediately to the north of Ladegårdsãen, while later activity along fault lines in the major valleys raised the sediments to their present altitude.

The mountains of Kim Fjelde, up to $700 \mathrm{~m}$ above sea level, are composed of late Palaeozoic to late Cretaceous sediments, which were deposited and displaced in the 'Wandel Hav Strike-Slip Mobile Belt' during strike-slip faulting along NW-SE trending faults in late Cretaceous to post-Palaeocene times (Hảkansson, 1979; Hăkansson \& Pedersen, 1982). The Kap København Formation may thus reflect a continuation of the tectonic activity in the mobile belt into Neogene/early Pleistocene times. 


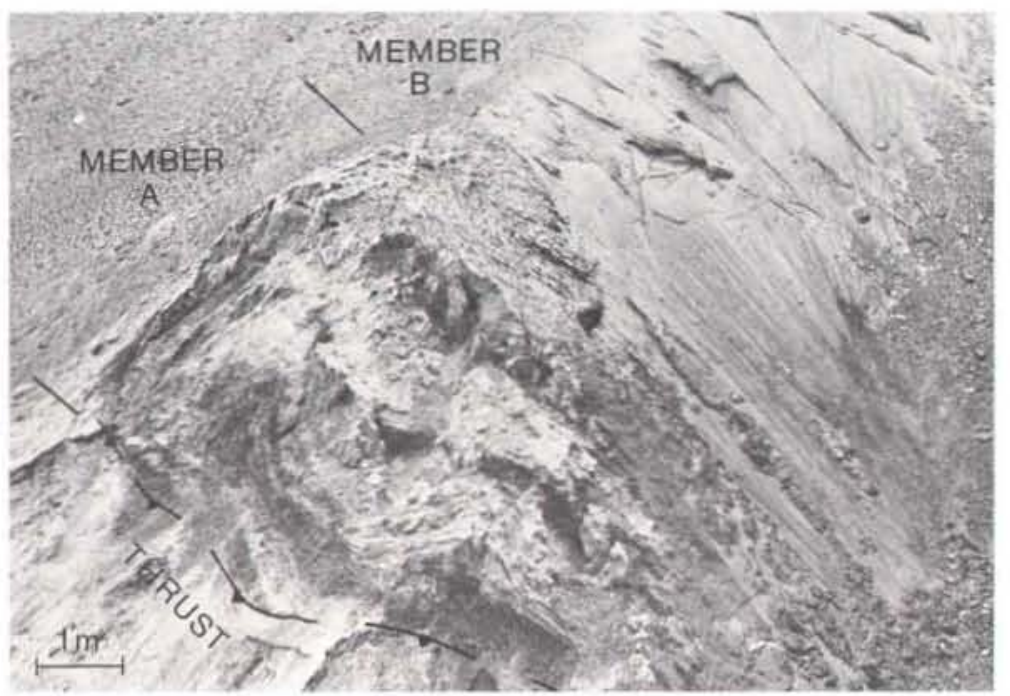

Fig. 7. Thrust-fault structure formed by glacial deformation of Kap Kobenhavn Formation sediments. A frontal anticline, c. $5 \mathrm{~m}$ high, is folded in the clay of member $\mathrm{A}$ that acted as a thrust sole. The sandy member B shows listric reverse faults.

\section{Correlation and age}

In northern Valdemar Glückstadt Land, on the opposite side of Independence Fjord, 50 $\mathrm{km}$ to the south of Kap København, marine sediments form a broad sill along the coast, 100 $\mathrm{m}$ above sea level. This deposit was cursorily investigated by Funder and Hjort $(1980),{ }^{14} \mathrm{C}$ dating of marine mollusc shells gave an 'infinite' age (Funder, 1982), while preliminary amino acid analysis yielded ratios identical to those obtained from the Kap København Formation. In beds of organic detritus seeds of Menyanthes were found (Bennike, unpublished). This plant grows in low and subarctic ponds with a northern limit at present 1000 $\mathrm{km}$ to the south in Greenland, but its seeds occur abundantly in the Kap København Formation (Fredskild \& Røen, 1982). From this evidence the deposit in northern Valdemar Glückstadt Land is tentatively correlated with the Kap København Formation.

In other parts of Greenland no deposits are known which can be correlated with the Kap København Formation with any reliability. Evidence for Neogene/Pleistocene tree growth is extremely sparse.

Conifer wood is associated with the Bjørnehiet Formation in Washington Land (lat. $80^{\circ} \mathrm{N}$ ). This occurrence is a lithified fluvial conglomerate which has been tentatively correlated with the Eureka Sound Formation (Palaeocene-Eocene), or the Beaufort Formation (Miocene) of Arctic Canada (Jepsen, 1981). Although a correlation between the Bjørnehiet and Kap København Formations is possible, the evidence is much too sparse to be definitive.

From West Greenland Bryan (1954) reported 20 per cent Picea among the sparse pollen found in a marine marl concretion, occurring as a glacial erratic. The Picea pollen was thought to reflect interglacial forest growth in the area. Marl concretions occur frequently in marine sediments ranging in age from early-mid Quaternary to Holocene (e.g. Kelly, 1975; 
Símonarson, 1981; Funder \& Símonarson, in press). However, pollen analysis of a number of concretions have failed to give evidence of anything but treeless, arctic vegetation (Funder, unpublished), neither is there any evidence for forest growth in pollen from the Plio/Pleistocene Lodin Elv Formation in East Greenland (Feyling-Hanssen et al., 1983). It is therefore suggested that until corroborative evidence can be found the pollen reported by Bryan (1954) should be regarded as long distance transport from areas outside Greenland, in a period when local pollen production was low.

Turning now to adjacent parts of the high arctic it is interesting to note that evidence for Neogene/Pleistocene forests is known from sites in the Canadian Arctic Archipelago.

On Banks Island, lat. $72^{\circ} \mathrm{N}$, remnants of the last forests in this region are found in the preglacial Worth Point Formation (Vincent, 1983). Palaeomagnetic measurements place these deposits in the Matuyama reversed epoch with an age of $0.7-2.5 \mathrm{Ma}$ (Vincent et al., in press). At this time open boreal-subarctic forest with Larix and Abies, and undergrowth of Alnus and dwarf-Betula grew in the area. In ponds the fresh water bryozoan Cristatella mucedo lived (Kuc, 1973, 1974a). Cristatella today has a low and subarctic distribution, and although it has not been found living in Greenland its statoblasts occur abundantly in the sediments of the Kap København Formation (Fredskild \& Røen, 1982). It is therefore interesting to note that N. Abrahamsen (personal communication, 1983) found reversed polarities in member B of the Kap København Formation. From this evidence the minimum age for the Kap København Formation is tentatively set at $0.7 \mathrm{Ma}$.

The flora found in the upper Beaufort Formation on Meighen Island (lat. $80^{\circ} \mathrm{N}$ ) also show similarities with that of the Kap København Formation. On Meighen Island northern boreal forest with Picea, Pinus and Thuja had an undergrowth of Alnus and Myrica, and also such arctic shrubs as Ledum, Vaccinium and Cassiope (Hills \& Matthews, 1974; Kuc, 1974b). The age of the upper Beaufort Formation determined by biostratigraphical correlation is Upper Miocene (Hills et al., 1974) or Lower Pliocene (Matthews, 1976, 1977).

In the North Atlantic region a number of marine mollusc species make their first appearance in the Tjörnes beds of northern Iceland (Einarsson et al., 1967; Norton, 1975). The age of the Tjörnes beds is 2.5-4.3 Ma (Albertsson, 1981). The presence of some of these species, notably Serripes groenlandicus, in unit B2 of the Kap København Formation may therefore provide a preliminary maximum age of $4.3 \mathrm{Ma}$ for the formation.

The Kap København Formation is tentatively dated in the interval 0.7 to $4.3 \mathrm{Ma}$. This estimate is supported by the preliminary results of analyses of foraminifer faunas in unit B2 (R. W. Feyling-Hanssen, personal communication, 1983). It is hoped that these investigations, as well as a detailed analysis of the mollusc faunas will supply a precise age for the deposits.

Acknowledgements. The expedition in 1983 was made possible by a grant from the Carlsberg Foundation. The Geological Survey of Greenland, the Meteorological Institute, the Ministry of Defence, and the Geological Survey of Denmark provided invaluable support in the field, and in the preparatory phase of the expedition.

C. Rasmussen prepared the illustrations, and $\mathrm{O}$. Winding (GGU) drew the topographical base for fig. 4 . 


\section{References}

Albertsson, K. J. 1981: On Tertiary tillites in Iceland. In Hambrey, M. J. \& Harland, W. B. (edit.) Earth's pre-Pleistocene glacial record, 562-565. Cambridge: C.U.P.

Bryan, M. S. 1954: Interglacial pollen spectra from Greenland. Danm. geol. Unders. (II) 80, 65-73.

Davies, W. E. 1963: Glacial geology of northern Greenland. Polarforschung 5, 94-103.

Einarsson, Th., Hopkins, D. M. \& Doell, R. R. 1967: The Stratigraphy of Tjörnes, Northern Iceland, and the history of the Bering Land Bridge. In Hopkins, D. M. (edit.) The Bering Land Bridge, 312325. Stanford: Stanford U. P.

Feyling-Hanssen, R. W., Funder, S. \& Petersen, K. Strand 1983: The Lodin Elv Formation; a PlioPleistocene occurrence in Greenland. Bull. geol. Soc. Denmark 31, 81-106.

Fredskild, B. \& Røen, U. 1982: Macrofossils in an interglacial peat deposit at Kap København, North Greenland. Boreas 11, 181-185.

Funder, S. 1982: ${ }^{14} \mathrm{C}$-dating of samples collected during the 1979 expedition to North Greenland. Rapp. Grønlands geol. Unders. 110, 9-14.

Funder, S. \& Hjort, C. 1980: A reconnaissance of the Quaternary geology of eastern North Greenland. Rapp. Grønlands geol. Unders. 99, 99-105.

Funder, S. \& Símonarson, L. A. in press: Bio- and aminostratigraphy of some Quaternary marine deposits in West Greenland. Can. J. Earth Sci.

Hills, L. V. \& Matthews, J. V. 1974: A preliminary list of fossil plants from the Beaufort Formation, Meighen Island, District of Franklin. In Report of Activities, Part B. Pap. geol. Surv. Can. 74-1, 224 226.

Hills, L. V., Klovan, J. E. \& Sweet, A. R. 1974: Juglans eocinerea n. sp., Beaufort Formation (Tertiary), southwestern Banks Island, Arctic Canada. Can. J. Bot. 52, 65-90.

Håkansson, E. 1979: Carboniferous to Tertiary development of the Wandel Sea Basin, eastern North Greenland. Rapp. Grønlands geol. Unders. 88, 73-85.

Håkansson, E. \& Pedersen, S. S. 1982: Late Paleozoic to Tertiary tectonic evolution of the continental margin in North Greenland. Mem. Can. Soc. Petrol. Geol. 8, 331-347.

Jepsen, H. 1981: The Bjørnehiet Formation: a faulted preglacial conglomerate, Washington Land, North Greenland. In Dawes, P. R. \& Kerr, J. W. (edit.) Nares Strait and the drift of Greenland: a conflict in plate tectonics. Meddr Grønland, Geosci. 8, 55-59.

Kelly, M. 1975: A note on the implications of two radiocarbon dated samples from Qaleragdlit imâ, South Greenland, Bull. geol. Soc. Denmark 24, 21-26.

Koch, L. 1923: Preliminary report upon the geology of Peary Land, Arctic Greenland. Am. J. Sci. 5, 189-199.

Kuc, M. 1973: Fossil statoblasts of Cristatella mucedo Cuvier in the Beaufort Formation and in interglacial and postglacial deposits of the Canadian Arctic. Pap. Geol. Surv. Can. 72-28, 12 pp.

Kuc, M. 1974a: The interglacial flora of Worth Point, western Banks Island. In: Report of Activities, Part B. Pap. geol. Surv. Can. 74-1, 227-231.

Kuc, M. 1974b: Fossil flora of the Beaufort Formation, Meighen Island, Northwest Territories. Pap. geol. Surv. Can. 74-1, 103-195.

Matthews, J. V. 1976: Evolution of the subgenus Cyphelophorus (genus Helophorus, hydrophilidae, Coleoptera): description of two new fossil species and discussion of Helophorus tuberculatus Gyll. Can. J. Zool. 54, 652-673.

Matthews, J. V. 1977: Coleoptera fossils: their possible value for dating and correlation of late Cenozoic sediments. Can. J. Earth Sci. 10, 2339-2347.

Mogensen, G. S. in press: Subfossil bryophytes from Pliocene or early Pleistocene, Kap København, North Greenland. Lindbergia 10.

Norton, P. E. P. 1975: Paleoecology of the Mollusca of the Tjörnes sequence, Iceland. Boreas 4, 97-110.

Símonarson, L. A. 1981: Upper Pleistocene and Holocene marine deposits and faunas on the north coast of Nûgssuaq, West Greenland. Bull. Grønlands geol. Unders. 140, 107 pp.

2 Rapport 120 
Vincent, J.-S. 1983: La géologie du Quaternaire et la géomorphologie de L'île Banks, Arctique Canadien. Mem. geol. Surv. Can. 405, 118 pp.

Vincent, J.-S., Morris, W. A. \& Occhietti, S. in press: Glacial and nonglacial sediments of Matuyama paleomagnetic age on Banks Island, Canadian Arctic Archipelago. Geology.

S. F. \& O. B.,

Geologisk Museum,

Øster Voldgade 5-7,

DK-1350 Copenhagen $K$.

G. S. M.,

Botanisk Museum,

Gothersgade 130,

DK-1123 Copenhagen $K$.

S. A. S. P.,

Geologisk Centralinstitut,

$\emptyset$ ster Voldgade 10 ,

DK-1350 Copenhagen $K$.
B. N. $-N$,

Biologisk Institut,

Odense Universitet,

Campusvej 55

6000 Odense,

Denmark.

K. S. P.,

Danmarks Geologiske Undersøgelse

Thoravej 31 DK-2400 Copenhagen NV.

\title{
Programme NordGrøn (PNG) 1983-1985: regional mapping and geological studies in western and central North Greenland
}

\author{
Peter R. Dawes
}

Programme NordGrøn (PNG) is planned as an onshore, regional mapping, and stratigraphic and structural study of the ice-free areas of northern Greenland between Humboldt Gletscher in the south-west $\left(80^{\circ} \mathrm{N}\right)$ and western Peary Land to the east $\left(c .45^{\circ} \mathrm{W}\right)-$ a region of about $45000 \mathrm{~km}^{2}$ (fig. 8). It is a sequel to the three-year programme carried out farther to the east in North Greenland in 1978-1980 (Peary Land to Kronprins Christian Land, see Henriksen, 1979, 1980, 1981 and GGU Reports 88 (1979), 99 (1980), 106 (1981). PNG is scheduled as a two-summer geological field activity in 1984 and 1985; in the summer of 1983, a three-man group visited the region to undertake logistic preparation and reconnaissance studies.

\section{Logistics}

The field activity will take place in June, July and August, with the main geological investigations concentrated in a period of nine to ten weeks. The activity will be carried out by 12 to 13 two-man geological teams, and some 14 support personnel including base camp staff and helicopter and fixed-wing crews - a total of about 40 participants per season. The field work will be supported by two small helicopters (Bell 206 Jet Rangers or Hughes 500) and a DHC-6 Twin Otter. 